\title{
Effect of defaunation on protein and fibre digestion in sheep fed on ammonia-treated straw-based diets with or without maize
}

\author{
BY K. USHIDA*, C. KAYOULI $\dagger$, S. DE SMET\$ AND J. P. JOUANY§ \\ Station de Recherches sur la Nutrition des Herbivores, Unité de la Digestion Microbienne, INRA, \\ Centre de Recherches de Clermont Ferrand-Theix, 63122 Ceyrat, France
}

(Received 23 November 1989 - Accepted 24 May 1990)

\begin{abstract}
Using a defaunating method which preserved bacteria and fungi in the rumen, the effect of protozoa on protein and fibre digestion was studied in six adult wethers in relation to the nature of the diet. Sheep were given daily, $42 \mathrm{~g}$ dry matter $(\mathrm{DM}) / \mathrm{kg}$ metabolic body-weight $\left(\mathrm{W}^{0.75}\right)$, one of two isonitrogenous diets: one contained ammonia-treated wheat straw as the only energy source (diet $S$ ) and the other was supplemented with maize grain pellets (diet SM). Mean daily intakes (g/d) of nitrogen, neutral-detergent fibre and acid-detergent fibre were respectively 22,573 and 373 for diet $S$ and 23,450 and 334 for diet SM. Elimination of protozoa increased duodenal non-ammonia-nitrogen flow. This result was mainly due to an increase in microbial protein flow and, to a lesser extent, to a higher dietary protein flow. Defaunation markedly increased the efficiency of microbial protein synthesis. Maize-grain supplementation had a net positive effect on this variable in defaunated sheep, but not in faunated sheep. Cell-wall carbohydrates were less well digested in the defaunated rumen, and the negative effect of defaunation was greatest with the diet SM. Intestinal fibre digestion increased in the defaunated sheep especially in those fed on diet SM, but not enough to compensate for the decrease in rumen digestion.
\end{abstract}

Protozoa: Fibre digestion: Protein digestion: Sheep

Defaunation was reported to be beneficial for the growth of young ruminants and for the wool production of sheep when diets deficient in rumen-undegradable protein and rich in soluble sugar were used (Bird \& Leng, 1978, 1984; Bird et al. 1979). These results suggested that defaunation might have a positive effect on the intestinal protein supply. This has been well evidenced in the last decade by a number of in vitro, in sacco and in vivo digestion trials (Demeyer \& Van Nevel, 1979; Kayouli et al. 1983, 1986; Veira et al. 1983; Ushida et al. 1984, 1986; Rowe et al. 1985; Ushida \& Jouany, 1985; Meyer et al. 1986).

Studies on the effect of defaunation on fibre digestion unlike those on protein digestion have been limited either to in vitro or in sacco experiments (Yoder et al. 1966; Jouany \& Senaud, 1979 a; Kayouli et al. 1983-84; Soetanto et al. 1985; Romulo et al. 1986; Ushida et al. 1987; Broudiscou et al. 1988; Kaneko et al. 1989). These published results, which were obtained from animals fed on diets supplemented with concentrate feed, indicate that defaunation reduces rumen fibrolytic activity. Recent enzymological studies also suggest that defaunation decreases the activity of polysaccharide hydrolases in the rumen (Coleman, 1986; Williams et al. 1988). According to Coleman (1985), 62\% of the total carboxymethylcellulase ( $E C$ 3.2.1.4; CMCase) activity in the rumen is associated with Atype protozoa. Williams \& Strachan (1984) also observed that the specific activities of CMC- and avicel (high - crystalline cellulose)-degrading enzymes were higher in protozoa than in bacteria isolated from the rumen of a cow fed on hay. But no in vivo digestion trials

\footnotetext{
Present addresses: * Faculty of Agriculture, Kyoto Prefectural University, Shimogamo, Kyoto 606, Japan.

$\dagger$ Chaire de Zootechnie, INAT, 1002 Tunis, Tunisia.

$\ddagger$ Research Center for Nutrition, Animal Husbandry and Meat Technology, State University of Ghent, 9230 Melle, Belgium.

$\S$ For reprints.
} 
have been conducted to confirm the importance of protozoa in fibre digestion. Moreover, an increase in fibrolytic activity after defaunation has been reported in sheep fed on low quality straw-based diets (Soetanto et al. 1985; Romulo et al. 1986). The reasons for these discrepancies in the effect of defaunation on fibre digestion are still unclear.

The effect of defaunation on cellulose utilization is known to be affected by the presence of dietary starch (Kreuzer et al. 1986); the negative effect of starch on cellulose utilization is greater in defaunated animals. Two isonitrogenous straw-based diets were, therefore, used in the present experiment; one contained ammonia-treated wheat straw as the only energy source, which was expected to develop a small protozoal population, and the other contained the same treated straw as well as maize grain, which was expected to develop a larger protozoal population and to have a negative effect on rumen fibre digestion. Thus, the effect of presence or absence of protozoa on rumen fibre digestion was examined with different sizes of protozoal population and in the presence or absence of the repressive factor, i.e. starch supplementation, for cellulolysis.

\section{MATERIALS AND METHODS}

\section{Animals and diets}

Six adult Texel wethers (60 kg body-weight (BW)) were used. Each sheep was fitted with simple rumen and duodenal cannulas. They were defaunated before the experiment (Jouany \& Senaud, 1979 b) and remained protozoa-free in the first period (defaunated period; DF). The defaunating method used was based on rumen emptying and washing. When emptying the rumen on the first day of defaunation, rumen content was carefully collected and frozen at $-15^{\circ}$ for $48 \mathrm{~h}$. Approximately 3 litres of thawed rumen contents were returned to the rumen just at the end of the defaunating treatment in order to allow bacteria and fungi to quickly re-establish. The sheep were re-inoculated during the second period (faunated period; F) with a B-type fauna (Entodinium spp., Eudiplodinium spp., Eremoplastron spp., Epidinium spp., Dasytricha ruminantium and Isotricha spp.) which was taken from grazing rumen-cannulated cows.

Two diets based on the same ammonia-treated wheat straw were given to the sheep at the rate of $42 \mathrm{~g}$ dry matter $(\mathrm{DM}) / \mathrm{kg}$ metabolic live weight $\left(\mathrm{W}^{0.75}\right)$ per d. One diet (S) contained treated straw as the only energy source, and $20 \%$ of straw was replaced by pelleted maize grain in the other diet (SM). The details of the diets are given in Table 1 . Straw was chopped into $50 \mathrm{~mm}$ long pieces. Maize grain and vitamin-mineral premix were given in pelleted forms. Fishmeal and ammonium sulphate were distributed as powder. All ingredients were mixed and given in twelve equal meals daily at $2 \mathrm{~h}$ intervals by means of an automatic feeder.

\section{Experimental design and sampling procedure}

The experiment consisted of two main periods, DF and F, further divided into two sub-periods. The six sheep were randomly divided into two groups of three animals. In the first sub-period, one group was fed on diet S, while the other received diet SM. In the second sub-period, the diets were switched over. Each sub-period consisted of $21 \mathrm{~d}$ adaptation and $12 \mathrm{~d}$ sampling (a $21 \mathrm{~d}$ adaptation period was also allowed between periods $\mathrm{DF}$ and $\mathrm{F}$ ): the first $7 \mathrm{~d}$ of the sampling period (days 1-7) were used for faeces collection and the following $2 \mathrm{~d}$ (days 8 and 9 ) for duodenal digesta collection.

The collections of rumen gas were made on day 10 and rumen digesta samples for ammonia and volatile fatty acid (VFA) determinations were made on day 11 . The rumen cannula plugs were replaced by those for gas sampling on day 10 (Jouany \& Senaud, $1979 \mathrm{c}$ ). Samples of rumen gas and digesta were collected four times daily, $1 \mathrm{~h}$ after feeding. 
Table 1. Composition of experimental diets

\begin{tabular}{|c|c|c|}
\hline Diet ... & $S$ & SM \\
\hline \multicolumn{3}{|l|}{ Ingredients $(\mathrm{g} / \mathrm{kg})$} \\
\hline Ammonia-treated wheat straw* & 895.5 & $716 \cdot 4$ \\
\hline Maize pellets & - & $179 \cdot 1$ \\
\hline Fishmeal & 59.7 & $59 \cdot 7$ \\
\hline Ammonium sulphate & $29 \cdot 9$ & $29 \cdot 9$ \\
\hline Vitamin-mineral premix $\uparrow$ & $14 \cdot 9$ & 14.9 \\
\hline \multicolumn{3}{|c|}{ Chemical composition ( $\mathrm{g} / \mathrm{kg}$ dry matter (DM)) } \\
\hline Organic matter & 862 & 885 \\
\hline Nitrogen & 26 & 26 \\
\hline Neutral detergent fibre & 652 & 505 \\
\hline Acid-detergent fibre & 422 & 375 \\
\hline Acid-detergent lignin & 66 & 52 \\
\hline Estimated rumen-degradable nitrogen§̧ & 17 & 16 \\
\hline $\mathrm{ME}(\mathrm{MJ} / \mathrm{kg} \mathrm{DM}) \S$ & 6.9 & $8 \cdot 1$ \\
\hline
\end{tabular}

S, straw diet; SM, straw and maize diet; ME, metabolizable energy.

* Cut $50 \mathrm{~mm}$ long.

$\dagger$ For details, see Ushida et al. (1986).

$\ddagger$ Klason lignin on acid-detergent residue.

$\S$ Calculated from nitrogen degradabilities and energy values for individual components (INRA, 1978).

The mean of these four determinations was then calculated. Rumen bacteria were isolated by centrifugation on the final day (day 12). Sampling procedures and sample treatments for faeces, duodenal and rumen digesta were as described elsewhere (Ushida et al. 1986).

A solution containing polyethylene glycol (PEG; molecular weight 4000) and ytterbium chloride was infused into the rumen via the cannula at the rate of $20 \mathrm{~g} \mathrm{PEG} / \mathrm{d}$ and $120 \mathrm{mg}$ $\mathrm{Yb} / \mathrm{d}$. Infusion of this marker solution was started 1 week before the sampling period. PEG was used as a solute marker and $\mathrm{Yb}$ as a particulate marker. The estimation of duodenal digesta flow was based on the concentrations of these markers in digesta samples and made by the dual-marker technique as described by Faichney (1975).

\section{Chemical analyses}

Analytical procedures for DM, organic matter (OM), nitrogen, ammonia, VFA, 2,6diaminopimelic acid (DAPA), nucleic acid-purine bases (PB) and PEG determinations were the same as previously described (Ushida et al. 1986). Rumen gases were analysed immediately after sampling by gas-liquid chromatography as described by Jouany (1978). $\mathrm{Yb}$ was determined as recommended by Ellis et al. (1982). Neutral-detergent fibre (NDF) and acid-detergent fibre (ADF) were determined separately by the method of Van Soest \& Wine (1967). Klason lignin (14 M-sulphuric acid-insoluble matter; ADL) was determined on acid-detergent residues. Values of NDF, ADF and lignin were corrected for their ash content. The starch in the digesta samples taken from the sheep fed on diet SM that had escaped rumen fermentation was eliminated by an amylase (EC 3.2.1.1) treatment before the NDF determination of the digesta samples; the same treatment was applied to diet SM: a $500 \mathrm{mg}$ sample was suspended in $20 \mathrm{ml}$ distilled water and heated to boiling point. After being cooled, an equal volume of $\alpha$-amylase solution $(50 \mathrm{mg} / 1$ phosphate buffer, $\mathrm{pH} 5 \cdot 8$ ) was added and incubated at $40^{\circ}$ for $16 \mathrm{~h}$. $\alpha$-Amylase was purchased from Wako Pure Chemical Ltd, Osaka, Japan.

Analysis of neutral sugars was done on the neutral-detergent residues. Acid-hydrolysis of cell walls, reduction of free sugars to their alditols and subsequent acetylation were 
achieved as described by Blakeney et al. (1983). The alditol acetates formed were quantitatively analysed by a similar method to that of Theander \& Aman (1979) using a GC-12A gas-liquid chromatograph (Shimadzu Seisakusho, Kyoto, Japan) equipped with a glass column $(3 \mathrm{~m} \times 3 \mathrm{~mm}$, i.d.) which was packed with $3 \% \mathrm{SP} 2340$ on Supelcoport $(100 / 200$ mesh). The detection was performed by a flame-ionization detector and calculations for each component were made using a C-R3A integrator (Shimadzu Seisakusho, Kyoto, Japan). Myo-Inositol was used as the internal standard.

Protozoa counts were made microscopically $1 \mathrm{~h}$ after feeding (three counts per sample) as described by Jouany et al. (1981). Changes in numbers were monitored every $3 \mathrm{~d}$ during the adaptation period. Protozoal population reached a stable state $9 \mathrm{~d}$ after treatment. Rumen anaerobic fungi were cultured by the method of Joblin (1981) for the estimation of their relative population size at the end of the adaptation period. Rumen fluids which were sampled $1 \mathrm{~h}$ after feeding, were serially diluted to $10^{-1}, 10^{-2}, 10^{-3}$ and $10^{-4}$ dilutions. Portions $(0.3 \mathrm{ml})$ of each diluted sample and antibiotic solution were inoculated to duplicate tubes which contained $4 \mathrm{ml}$ agar medium.

\section{Statistical analyses}

The experimental design used was in fact two main experimental periods (DF and F), with two diets and with one crossover in each experimental period. Thus, the two experimental periods were first analysed separately by the analysis of variance with the following factors: sheep (df 5), period ( df 1), diet (df 1) and residual (df 4). When the residual variances were confirmed to be similar by $F$ test, then the two analyses were pooled to give $4+4=8$ residual df. The data were analysed to appreciate the effect of protozoa (df 1), of diet (df 2 ), of sheep (df 10), and of sub-period (df 2).

\section{RESULTS}

All the sheep remained protozoa-free during period DF. Sheep fed on diet S and SM had $0.42 \times 10^{5}\left(\mathrm{SE} 0.04 \times 10^{5}\right)$ protozoa per $\mathrm{ml}$ and $1.05 \times 10^{5}\left(\mathrm{SE} 0.52 \times 10^{5}\right)$ protozoa per ml respectively during period F. The microfauna was composed mainly of Entodinium spp. ( $80 \%$ of total population) in both diets. Epidinium ecaudatum accounted for 5 and $9 \%$ of the population of diets S and SM respectively. E. ecaudatum ecaudatum was the dominant species in the Epidinium mixture with diet $S$, while the additional maize-grain pellets favoured E. ecaudatum caudatum. Eremoplastron spp. and Eudiplodinium maggii also increased their number with diet SM but to a lesser extent. Holotrichs were not affected and represented only $0.5-1 \%$ of the population. Anaerobic fungi numbers (no. of viable spores $\times 10^{3} / \mathrm{ml}$ rumen fluid) were $2 \cdot 7$ (SE 1.0) and 7.5 (SE 4.5) in the rumen of defaunated and faunated sheep respectively fed on diet $\mathbf{S}$. With diet SM, the corresponding numbers were $2 \cdot 8$ (SE 0.9$)$ and $10 \cdot 6$ (SE $4 \cdot 1)$ in the defaunated and faunated sheep respectively.

The concentration of methane in rumen gas was slightly higher in faunated than in defaunated animals, while that of carbon dioxide was greater in defaunated sheep (Table 2). The presence of protozoa increased the total rumen VFA concentration, but the molar proportion of each acid in the mixture was not affected, except for butyric acid. The production of butyric acid was significantly enhanced by protozoa with both diets (Table 2).

Defaunation increased the non-ammonia-N (NAN) flow to the duodenum of sheep, mainly because of a significantly greater microbial-N (MN) flow in defaunated sheep (Table 3). Maize supplementation had a positive effect on total N (TN), NAN and MN flow especially in defaunated sheep.

The differences between the values of MN flow estimated by $\mathrm{PB}$ and bacterial $\mathrm{N}$ estimated by DAPA, possibly correspond to protozoal $\mathrm{N}$ in the faunated period. The 
Table 2. Effect of defaunation on the volatile fatty acid (VFA) concentration and molar proportion, gas composition and ammonia concentration in the rumen of sheep fed on strawbased diets with $(S M)$ or without $(S)$ maize

\begin{tabular}{|c|c|c|c|c|c|c|c|c|c|c|c|}
\hline \multirow{3}{*}{$\begin{array}{l}\text { Experimental } \\
\text { period }\end{array}$} & \multirow[b]{3}{*}{ Diet\$ } & \multirow{3}{*}{$\begin{array}{l}\text { Ammonia- } \\
\text { nitrogen } \\
(\mathrm{mg} / \mathrm{l})\end{array}$} & \multirow{3}{*}{$\begin{array}{c}\text { Total } \\
\text { VFA } \\
\text { (mmol/l) }\end{array}$} & \multirow{2}{*}{\multicolumn{6}{|c|}{ Molar proportion $(\mathrm{mmol} / \mathrm{mol})$ of: }} & \multicolumn{2}{|c|}{$\begin{array}{l}\text { Gas composition } \\
(\mathrm{ml} / \mathrm{l})\end{array}$} \\
\hline & & & & & & & & & & \multirow{2}{*}{$\begin{array}{l}\text { Carbon } \\
\text { dioxide }\end{array}$} & \multirow[b]{2}{*}{ Methane } \\
\hline & & & & $\mathrm{C}_{2}$ & $\mathrm{C}_{3}$ & $\mathrm{iC}_{4}$ & $\mathrm{C}_{4}$ & $\mathrm{iC}_{5}$ & $\mathrm{C}_{5}$ & & \\
\hline DF & S & $163 \cdot 1$ & $70 \cdot 3 \ddagger$ & 740 & 190 & 5 & $54 \ddagger$ & 6 & $6 \dagger$ & 583 & 358 \\
\hline DF & $\mathrm{SM}$ & $149 \cdot 1$ & $57.8^{\circ}$ & 717 & 186 & 7 & $73^{+}$ & 10 & 8 & 598 & 341 \\
\hline $\mathrm{F}$ & $\mathbf{S}$ & $255 \cdot 1$ & $72 \cdot 4_{+}^{+}$ & 710 & 198 & 6 & $73 \ddagger$ & 6 & $6+$ & 534 & 363 \\
\hline \multirow[t]{3}{*}{$\mathrm{F}$} & SM & $277 \cdot 9$ & $66 \cdot 0^{+}$ & 694 & 194 & 7 & $88^{+}$ & 7 & 8 & 567 & 367 \\
\hline & SEM & $4 \cdot 2$ & 1.0 & 4 & 3 & 1 & 1 & 1 & 1 & 7 & 2 \\
\hline & \multicolumn{9}{|c|}{ Statistical significance of pooled analysis } & & \\
\hline $\mathrm{DF} v . \mathrm{F}$ & & ** & NS & $* *$ & NS & NS & $* *$ & NS & NS & * & * \\
\hline$S \vee . S M$ & & NS & $* *$ & $*$ & NS & * & ** & * & $* *$ & NS & NS \\
\hline
\end{tabular}

DF, defaunated sheep; $F$, faunated sheep; NS, not significant; $C_{2}$, acetic acid; $C_{3}$, propionic acid; $i_{4}$, isobutyric acid; $\mathrm{C}_{4}$, butyric acid; $\mathrm{iC}_{5}$, isovaleric acid; $\mathrm{C}_{5}$, valeric acid.

$* P<0.05, * * P<0.01$.

The effect of diet within each period (DF and $F$ ) was significant: $† P<0.05, \ddagger P<0.01$.

$\S$ For details, see Table 1.

Table 3. Effect of defaunation on nitrogen digestion $(\mathrm{g} / \mathrm{d})$ of sheep fed on straw-based diets with $(S M)$ or without $(S)$ maize

\begin{tabular}{|c|c|c|c|c|c|c|c|}
\hline \multirow{2}{*}{$\begin{array}{l}\text { Experimental period... } \\
\text { Diet } \$\end{array}$} & \multicolumn{2}{|c|}{ DF } & \multicolumn{2}{|c|}{$\mathrm{F}$} & \multicolumn{3}{|c|}{$\begin{array}{c}\text { Statistical significance } \\
\text { of pooled analysis }\end{array}$} \\
\hline & $\mathbf{S}$ & $\mathrm{SM}$ & $S$ & SM & SEM & $\mathrm{DF} v . \mathrm{F}$ & $\mathrm{S} v . \mathrm{SM}$ \\
\hline Intake & $22 \cdot 6$ & $22 \cdot 1$ & $21 \cdot 7$ & 23.0 & $0 \cdot 1$ & NS & NS \\
\hline $\begin{array}{l}\text { Duodenal flow of: } \\
\text { TN } \\
\text { NAN } \\
\text { MN (DAPA) } \\
\text { MN (PB) }\end{array}$ & $\begin{array}{c}17 \cdot 2 \dagger \\
16 \cdot 1 \dagger \\
7 \cdot 8 \dagger \\
8 \cdot 4\end{array}$ & $\begin{array}{r}20 \cdot 6 \\
19 \cdot 3 \\
10 \cdot 2 \\
9 \cdot 3\end{array}$ & $\begin{array}{l}14 \cdot 1 \ddagger \\
12 \cdot 8 \\
4 \cdot 9 \\
6 \cdot 0\end{array}$ & $\begin{array}{r}15 \cdot 9 \\
13 \cdot 3 \\
5 \cdot 9 \\
6 \cdot 6\end{array}$ & $\begin{array}{l}0 \cdot 3 \\
0 \cdot 3 \\
0 \cdot 2 \\
0 \cdot 1\end{array}$ & $\begin{array}{l}* * \\
* * \\
* * \\
* *\end{array}$ & $\begin{array}{l}* * \\
* \\
* * \\
\text { NS }\end{array}$ \\
\hline Faecal excretion & $7 \cdot 1$ & $7 \cdot 2$ & $6 \cdot 0$ & $5 \cdot 5$ & $0 \cdot 1$ & ** & NS \\
\hline
\end{tabular}

DF, defaunated sheep; F, faunated sheep; NS, not significant ; TN, total nitrogen; NAN, non-ammonia-N ; MN, microbial N; DAPA, 2,6-diaminopimelic acid; PB, nucleic acid-purine bases.

$* P<0.05, * * P<0.01$.

The effect of diet within each period (DF and F) was significant: $\dagger P<0.05, \ddagger P<0.01$.

$\S$ For details, see Table 1.

contribution of protozoal $\mathrm{N}$ to the duodenal $\mathrm{MN}$ was approximately 18 and $10 \%$ for sheep fed on diet S and diet SM respectively. The efficiency of rumen microbial protein synthesis ( $\mathrm{g} \mathrm{N}$ incorporated $/ \mathrm{kg}$ OM apparently digested in the rumen) was significantly higher $(P<0.01)$ in the defaunated sheep (Table 4). Maize supplementation promoted greater efficiency in defaunated sheep, but failed to improve values in faunated sheep. Dietary $\mathrm{N}$ degradation in the rumen, which was estimated as previously reported (Ushida et al. 1986), was lower in defaunated sheep (Table 4).

A decrease in OM digestibility in the rumen and in the whole tract due to defaunation was observed (Table 5). 
Table 4. Efficiency of microbial protein synthesis and feed nitrogen degradability in defaunated and faunated sheep fed on straw-based diets with $(S M)$ or without $(S)$ maize

\begin{tabular}{|c|c|c|c|c|c|c|c|}
\hline \multirow{2}{*}{$\begin{array}{l}\text { Experimental period... } \\
\text { Diett... }\end{array}$} & \multicolumn{2}{|c|}{$\mathrm{DF}$} & \multicolumn{2}{|c|}{$\mathrm{F}$} & \multicolumn{3}{|c|}{$\begin{array}{l}\text { Statistical significance } \\
\text { of pooled analysis }\end{array}$} \\
\hline & $S$ & SM & $S$ & $\mathrm{SM}$ & SEM & $\mathrm{DF} v . \mathrm{F}$ & $\mathbf{S} v \cdot \mathbf{S M}$ \\
\hline \multicolumn{8}{|l|}{$\begin{array}{l}\text { Efficiency of microbial } \\
\text { protein synthesis } \\
\text { (g N/kg OMDR) }\end{array}$} \\
\hline DAPA & $24 \cdot 4 \dagger$ & $35 \cdot 7$ & $15 \cdot 2$ & $16 \cdot 1$ & $1 \cdot 4$ & $* *$ & NS \\
\hline PB & $26 \cdot 3$ & $32 \cdot 5$ & $17 \cdot 5$ & $17 \cdot 8$ & $1 \cdot 5$ & $* *$ & NS \\
\hline \multicolumn{8}{|c|}{$\begin{array}{l}\text { Feed degradability in the } \\
\text { rumen ( } \mathrm{g} / \mathrm{kg} \mathrm{N} \text { intake) }\end{array}$} \\
\hline PB & 702 & 594 & 721 & 752 & 16 & $* *$ & NS \\
\hline
\end{tabular}

DF, defaunated sheep; F, faunated sheep; OMDR, organic matter apparently digested in the rumen; DAPA, 2,6-diaminopimelic acid; PB, nucleic acid-purine bases; NS, not significant.

** $P<0.01$.

The effect of diet within each period (DF and F) was significant : $\uparrow P<0.05$.

\$ For details, see Table 1 .

The presence of protozoa significantly improved rumen and total tract digestion of almost all the fibre components, while maize supplementation significantly reduced the fibre digestion in rumen and total tract (Table 5). The differences between DF and F were smaller with diet $\mathbf{S}$ than with diet SM. Intestinal fibre digestion increased in the defaunated sheep especially in those fed on diet SM, but not sufficiently to fully recover the decrease in rumen digestion. Post-rumen compensation in defaunated sheep was nevertheless appreciable with diet $S M$ in contrast to that with diet $S$. In the latter, there was virtually no compensation. This indicates that the potentially digestible fraction that escaped rumen fermentation was larger in defaunated sheep fed on diet SM. Xylose digestibilities in the rumen were virtually the same as those of glucose. Arabinose digestibilities in the rumen were always higher than those of glucose and xylose. Xylose content in the NDF fraction slightly increased at the expense of arabinose during digestion in the rumen, which suggests that the arabinose component was digested more rapidly than the xylose component of the hemicellulosic fraction of the cell wall. Values for mannose and galactose intakes and digestibilities are pooled in Table 5 , because these sugars made a minor contribution to overall digestion.

\section{DISCUSSION}

Contrary to many other papers on the effect of defaunation, especially those using antiprotozoal chemicals (Eadie $\&$ Shand, 1981), the defaunating method used in the present experiment itself might not disturb the re-establishment of bacterial and fungal population. This mild freezing and thawing treatment killed protozoa, but probably not fungal thalli and bacteria which rapidly colonized on (in) the plant fragments. Indeed, a usual level (several colonies at $10^{-3}$ dilution) of fungal population was seen in the roll-tube when thawed rumen contents were inoculated (Ushida, unpublished observation).

\section{Dietary effect on the rumen microbial ecosystem}

Ammonia-treated straw promoted a relatively small protozoal population. Supplementation of maize grain enhanced the development of the protozoal population. Entodinium spp. were the most favoured, while holotrichs were not affected by maize supplementation. 
Table 5. Digestion of organic matter $(O M)$, neutral-detergent fibre $(N D F)$, acid-detergent fibre $(A D F)$ and neutral sugars in NDF fraction in defaunated and faunated sheep fed on straw-based diets with $(S M)$ or without $(S)$ maize

\begin{tabular}{|c|c|c|c|c|c|c|c|}
\hline \multirow{2}{*}{$\begin{array}{l}\text { Experimental period ... } \\
\text { Diet§... }\end{array}$} & \multicolumn{2}{|c|}{ DF } & \multicolumn{2}{|c|}{ F } & \multirow[b]{2}{*}{ SEM } & \multicolumn{2}{|c|}{$\begin{array}{l}\text { Statistical significance } \\
\text { of pooled analysis }\end{array}$} \\
\hline & $S$ & SM & $s$ & SM & & $\mathrm{DF} v \cdot \mathrm{F}$ & $\mathrm{S} v . \mathrm{SM}$ \\
\hline \multicolumn{8}{|l|}{ Intake $(\mathrm{g} / \mathrm{d})$} \\
\hline OM & $743 \cdot 2 \ddagger$ & 778.2 & $760 \cdot 7 \ddagger$ & $789 \cdot 0$ & $2 \cdot 0$ & $-\|$ & - \\
\hline NDF & $567 \cdot 3 \ddagger$ & $448 \cdot 0$ & $578 \cdot 1 \ddagger$ & $450 \cdot 7$ & 1.7 & NS & ** \\
\hline$A D F$ & $367.9 \ddagger$ & $332-7$ & $377 \cdot 17$ & $334 \cdot 4$ & $1 \cdot 1$ & - & - \\
\hline $\mathrm{NDF}-\mathrm{ADF}$ & $199 \cdot 3 \ddagger$ & $115 \cdot 3$ & $201 \cdot 1+$ & 116.4 & 0.7 & NS & ** \\
\hline $\mathrm{ADF}-\mathrm{ADL}$ & $312.9 \pm$ & $285-4$ & $318 \cdot 1$ & $287 \cdot 6$ & 0.9 & NS & $* *$ \\
\hline Arabinose & $23 \cdot 2 \ddagger$ & $18 \cdot 6$ & $23 \cdot 6 \ddagger$ & 18.7 & 0.1 & - & - \\
\hline Xylose & $184 \cdot 1 \ddagger$ & $140 \cdot 3$ & $187.6 \ddagger$ & $141 \cdot 2$ & 0.6 & - & - \\
\hline Mannose + galactose & $9 \cdot 3 \ddagger$ & $4-8$ & $9 \cdot 4 \ddagger$ & 4.9 & $0 \cdot 1$ & NS & ** \\
\hline Glucose & $305 \cdot 8 \ddagger$ & $230 \cdot 6$ & $311 \cdot 6 \ddagger$ & $232 \cdot 0$ & 0.9 & 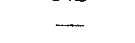 & - \\
\hline \multicolumn{8}{|l|}{ Digestibility in rumen } \\
\hline OM & 0.439 & 0.392 & 0.455 & 0.500 & 0.011 & * & NS \\
\hline $\mathrm{NDF}$ & $0.588 \ddagger$ & 0.409 & $0.639 \ddagger$ & 0.592 & 0.003 & ** & $* *$ \\
\hline $\mathrm{ADF}$ & $0.580 \ddagger$ & 0.455 & 0.596 & 0.597 & 0.005 & $* *$ & $* *$ \\
\hline $\mathrm{NDF}-\mathrm{ADF}$ & $0.603 \ddagger$ & $0 \cdot 268$ & $0.720 \ddagger$ & 0.576 & $0 \cdot 010$ & ** & $* *$ \\
\hline $\mathrm{ADF}-\mathrm{ADL}$ & $0.628 \ddagger$ & 0.513 & 0.655 & 0.662 & 0.004 & ** & ** \\
\hline Arabinose & $0.725 \dagger$ & 0.611 & $0.792 \ddagger$ & 0.699 & 0.008 & $* *$ & ** \\
\hline Xylose & $0.625 \ddagger$ & 0.426 & 0.697 & 0.647 & 0.005 & ** & ** \\
\hline Mannose + galactose & $0.739 \ddagger$ & 0.389 & $0.815 \ddagger$ & 0.629 & 0.009 & $* *$ & ** \\
\hline Glucose & 0.645 & 0.427 & 0.685 & 0.602 & 0.006 & ** & ** \\
\hline \multicolumn{8}{|l|}{ Digestibility in total tract } \\
\hline $\mathrm{OM}$ & $0.554 \uparrow$ & 0.582 & $0.596 \ddagger$ & 0.669 & 0.002 & ** & ** \\
\hline NDF & 0.651 & 0.575 & $0.694^{4}$ & 0.662 & 0.004 & ** & ** \\
\hline $\mathrm{ADF}$ & 0.620 & 0.587 & 0.656 & 0.670 & 0.004 & ** & NS \\
\hline $\mathrm{NDF}-\mathrm{ADF}$ & $0.708 \ddagger$ & 0.537 & $0.766 \ddagger$ & 0.638 & 0.005 & ** & ** \\
\hline $\mathrm{ADF}-\mathrm{ADL}$ & $0.663 \ddagger$ & 0.632 & $0.706^{\circ}$ & 0.723 & 0.003 & ** & * \\
\hline Arabinose & 0.768 & 0.657 & $0.803 \ddagger$ & 0.728 & 0.004 & ** & $* *$ \\
\hline Xylose & $0.679 \ddagger$ & 0.601 & $0.735^{7}$ & 0.690 & 0.005 & ** & *** \\
\hline Mannose + galactose & $0.795 \dagger$ & 0.583 & $0.853 \ddagger$ & 0.721 & 0.007 & ** & ** \\
\hline Glucose & $0.692 \dagger$ & 0.621 & 0.756 & 0.702 & 0.005 & $* *$ & ** \\
\hline
\end{tabular}

DF, defaunated sheep; F, faunated sheep; NS, not significant; ADL, Klason lignin on ADF

$* P<0.05,{ }^{* *} P<0.01$.

The effect of diet within each period (DF and F) was significant : $\uparrow P<0 \cdot 05, \ddagger P<0 \cdot 01$.

$\S$ For details, see Table 1.

\|V Values cannot be pooled, because the residual variances were not similar.

Maize grain favoured E.ecaudatum caudatum more than E. ecaudatum ecaudatum; approximately two-thirds of the Epidinium mixture were of caudatum-form with diet SM and less than one-quarter with diet $S$. The reasons for this phenomenon were unclear.

Effects of protozoa and diet on anaerobic colony counts of rumen phycomycete fungi were not statistically significant, because of the large variations between animals. However, inoculation of protozoa decreased colony counts of fungal spores in four of the six sheep fed on diet $S$, while it increased colony counts in five of the six sheep fed on diet SM. This possibly suggests the presence of interaction between protozoa and maize supplementation. Since concentrate feed decreases the numbers of rumen fungi (Gordon, 1984), active elimination of starch by protozoa may have a stimulating effect on fungal development. The increase in fungal population observed in faunated sheep fed on diet SM may not be 
inconsistent with enhanced fibre digestion in the rumen. More research is required on the ecological relationships between protozoa and fungi and the quantitative contribution of fungi to rumen fermentation under various dietary conditions.

\section{Effects of defaunation and maize on microbial protein synthesis}

NAN supply to the intestine increased by $26 \%$ on diet $S$ and by $45 \%$ on diet SM as a result of defaunation. This is in line with recent results of Veira et al. (1983), Ushida et al. (1984, 1986), Rowe et al. (1985), Kayouli et al. (1986) and Meyer et al. (1986). These increases in NAN supply were mainly due to a larger microbial $\mathrm{N}$ flow.

It is interesting that the responses of microbial protein synthesis to dietary maize supplementation were quite different between defaunated and faunated rumen populations. Appropriate amounts of maize grain supplying a readily digestible OM to micro-organisms generally improve microbial protein synthesis (Stern \& Hoover, 1979). However, the microbial- $N$ flow and the efficiency of microbial protein synthesis increased only in defaunated sheep (Tables 3 and 4). There was virtually no effect of maize supplementation on these variables in faunated sheep. Compared with diet $\mathrm{S}$, maize supplementation increased the microbial-N flow in the small intestine only in defaunated sheep. With the starch-supplemented diet, the number of protozoa increased; the absence of effect noted on the microbial-N flow in the duodenum of faunated animals can be explained by the selective retention of protozoa in the rumen and by recycling of their $N$ (Weller \& Pilgrim, 1974; Harrison \& McAllan, 1980; Leng, 1982). The low contribution of protozoal $\mathrm{N}$ in the duodenal- $\mathrm{N}$ flow only compensated for the decrease in bacterial $\mathrm{N}$ generally observed after inoculation of protozoa in a defaunated rumen (Jouany et al. 1988). Considering the terms 'total' and 'net' synthesis (Demeyer \& Van Nevel, 1979), both were probably increased in defaunated rumen by the maize supplementation, but only 'total' synthesis was increased in faunated rumen. An increase in the difference between 'total' and 'net' synthesis in the faunated rumen is the result of an increase in the degradation (autolysis and predation) of microbial- $\mathrm{N}$, presumably due to protozoal predation of bacteria. Increases in protozoal population in the present experiment as a result of maize supplementation significantly impaired protein availability to the host.

\section{Effect of defaunation on rumen fibre digestion}

Detergent analysis and neutral sugar analysis agreed relatively well: 'ADF minus ADL' and glucose, and 'NDF minus ADF' and xylose. Both methods indicated that defaunation resulted in a general decrease in rumen fibre digestion which was not completely compensated for by post-rumen digestion. However, the effects of defaunation on rumendigestion of each fibre component were not totally uniform for both diets; the digestion of both hemicellulosic components ('NDF minus ADF', arabinose, xylose) and cellulosic components (ADF, 'ADF minus ADL', glucose) were significantly decreased by defaunation when diet SM was given, whereas only the digestion of hemicellulosic components was greatly affected in the sheep given diet $\mathrm{S}$. The cellulolytic rumen organisms in faunated sheep are composed of a mixture of bacteria, fungi and large entodiniomorphid protozoa, all of which also have a hemicellulolytic activity (Hungate, 1966; Williams \& Coleman, 1985; Williams \& Orpin, 1987). Defaunation does not merely eliminate protozoa, but must also affect the density and activity of other microbial populations. The differences between defaunated and faunated animals, thus, cannot be entirely attributable to the specific function of protozoa. No bacteriological survey was made in the present experiment. Furthermore, the effects of defaunation on the population size of the bacterial groups, especially the cellulolytic group, are not fully understood (Ushida et al. 1990), and this makes discussion of the present results difficult. For example, it is unclear why 
defaunation greatly affected only hemicellulose digestion in the sheep fed on diet $\mathbf{S}$. The effects of defaunation on rumen fibre digestion in these sheep were clearer, however, and the results suggest that there are some inter-relationships between dietary starch and protozoa in fibre digestion. As far as the presence of starch is concerned, all protozoal species, even non-cellulolytic small entodinia, should be taken into account. The present experiment was conducted using a natural B-type fauna, which was characterized by the presence of a potent cellulolytic and hemicellulolytic species, Epidinium spp., but $80 \%$ of the population consisted of Entodinium spp., which have little or no cellulolytic activity (Coleman, 1985). Jouany \& Senaud (1979a) and Ushida et al. (1987) observed that the presence of Entodinium spp. apparently improved rumen cellulolysis. Bacterial CMCase activity increases (2.5-fold more active than that in defaunated rumen) as a result of faunation with Entodinium spp. (Coleman, 1986). A tentative explanation of this indirect enhancement of cellulolysis is that non-cellulolytic protozoa favour the growth of cellulolytic flora by: (1) restricting the development of amylolytic flora, as a result of the ingestion of starch granules by protozoa or the selective ingestion of amylolytic bacteria, or both, (Kurihara et al. 1968, 1978) and by; (2) preventing pH drop due to utilization of lactic acid (Chamberlain et al. 1983) and the slow utilization of readily fermentable substrates by protozoa. These are likely to be observed in conditions where animals receive concentrate feed. Faunation with Entodinium spp. did not modify the digestibility of ADF when only grass hay was given to sheep, but the protozoa improved ADF digestion when large amounts of readily fermentable carbohydrates were given (Jouany \& Senaud, 1982, 1983). This dietary carbohydrate-dependent effect of Entodinium spp. has also been confirmed in in vitro experiments: the addition of maize starch to in vitro culture severely depressed the cellulolytic activity of defaunated rumen populations, whereas it had no effect on the cellulolytic activity when Entodinium spp. were present (Kaneko et al. 1989). Therefore, it is likely that the present results on sheep fed on diet SM were due to the indirect action of entodiniomorphid protozoa, and in particular of small entodinia. In addition to this, the direct participation of cellulolytic large entodiniomorphid protozoa (Eudiplodinium spp., Eremoplastron spp., Epidinium spp.), in fibre degradation certainly had some effect, because the quantitative contribution of these protozoa to rumen CMCase activity is significant (Coleman, 1986), and they have potent hemicellulolytic depolymerases and glycoside hydrolases (Williams et al. 1984; Williams \& Coleman, 1985). An increase in their numbers due to maize supplementation is, therefore, not inconsistent with an increase in rumen fibre digestion. It would seem, therefore, that the effects of defaunation on digestion depend, at least in part, on the size and type of the protozoal population.

The authors are grateful to Miss Paulette Journaix, Mrs Marie-Paule Girard, Miss Hanna Zebrowska for their help in analytical work and to Mr L. L'Hotelier, Mr M. Fabre and Mr $\mathrm{P}$. Pichon for the care of experimental animals and to $\mathrm{Mr}$ J. Lefaivre for surgical preparation of sheep. The authors wish to thank Dr G. Fonty for his co-operation in the culture of rumen fungi and to Dr $\mathrm{H}$. Iwaisaki for his co-operation in the statistical work. The authors (K. U., C.K. and S.D.) are indebted to the Institut National de la Recherche Agronomique for a grant to work at Centre de Recherches de Clermont Ferrand-Theix.

\section{REFERENCES}

Bird, S. H., Hill, H. K. \& Leng, R. A. (1979). The effects of defaunation of the rumen on the growth of lambs on low-protein high-energy diet. British Journal of Nutrition 42, 81-87.

Bird, S. H. \& Leng, R. A. (1978). The effects of defaunation of the rumen on the growth of cattle on low-protein high-energy diets. British Journal of Nutrition 40, 163-167.

Bird, S. H. \& Leng, R. A. (1984). Further studies on the effects of the presence or absence of protozoa in the rumen on live-weight gain and wool growth of sheep. British Journal of Nutrition 52, 607-611. 
Blakeney, A. B., Harris, P. J., Henry, R. J. \& Stone, B. A. (1983). A simple and rapid preparation of alditol acetates for monosaccharide analysis. Carbohydrate Research 113, 291-299.

Broudiscou, L., Van Nevel, C. J., Demeyer, D. 1. \& Jouany, J. P. (1988). Addition d'hydrolysat d'huile de soja dans la ration de mouton. [Addition of a soybean oil hydrolysate to a sheep diet and its effect on in sacco degradation of straw and cellulose.] Reproduction, Nutrition, Développement 28, $159-160$.

Chamberlain, D. G., Thomas, P. C. \& Anderson, F. J. (1983). Volatile fatty acid proportions and lactic acid metabolism in the rumen in sheep and cattle receiving silage diets. Journal of Agricultural Science, Cambridge 101, $47 \cdot 58$.

Coleman, G.S. (1985). The celiulase content of 15 species of entodiniomorphid protozoa, mixed bacteria and plant debris isolated from ovine rumen. Journal of Agricultural Science, Cambridge 104, 349-360.

Coleman, G. S. (1986). The distribution of carboxymethylcellulase between fractions taken from the rumen of sheep containing no protozoa or one of five different protozoal populations. Journal of Agricultural Science, Cambridge 106, 121-127.

Demeyer, D. I. \& Van Nevel, C. J. (1979). Effect of defaunation on the metabolism of rumen micro-organisms. British Journal of Nutrition 42,515-524.

Eadie, J. M. \& Shand, W. J. (1981). The effect of synperonic NP9 upon ciliate-free and faunated sheep. Proceedings of the Nutrition Society $40,113 \mathrm{~A}$.

Ellis, W. C., Lascano, C., Teeter, T. \& Owens, F. N. (1982). Solute and particulate flow markers. In Protein Requirements for Catle, pp. 37-56 [F. N. Owens, editor]. Still Water, Oklahoma: Oklahoma State University.

Faichney, G. J. (1975). The use of markers to partition digestion within the gastro-intestinal tract of ruminants. In Digestion and Metabolism in the Ruminant, pp. 26I-276 [I. W. McDonald and A. C. I. Warner, editors] Armidale, NSW: University of New England Publishing Unit.

Gordon, G. L. R. (1984). The potential for manipulation of rumen fungi. Reviews in Rural Science 6, $124-128$.

Harrison, D. G. \& McAllan, A. B. (1980). Factors affecting microbial growth yields in the reticulo-rumen. In Digestive Physiology and Metabolism in Ruminants, pp. 205-226 [Y. Ruckebusch and P. Thivend, editors]. Lancaster: MTP Press Ltd.

Hungate, R. E. (1966). The Rumen and Its Microbes. New York: Academic Press.

INRA (1978). Alimentation des Ruminants, Versailles, France: INRA Publications.

Joblin, K. N. (1981). Isolation, enumeration, and maintenance of rumen anaerobic fungi in roll tubes. Applied and Environmental Microbiology 42, 1119-1122.

Jouany, J. P. (1978). Contrihution à létude des protozoaires ciliés du rumen: leur dynamique, leur rôle dans la digestion et leur intèrêt pour le ruminant. Thèse de docteur es sciences, Université de Clermont 11.

Jouany, J. P., Demeyer, D. 1. \& Grain, J. (1988). Effect of defaunating the rumen. Animal Feed Science und Te'chnology 21, 229-265.

Jouany, J. P. \& Senaud, J. (1979a). Role of rumen protozoa in the digestion of food cellulosic materials. Annales de Recherches Vétérinaires 10, 261-263.

Jouany, J. P. \& Senaud, J. (1979 $b$ ). Defaunation du rumen de mouton. (Defaunation of the sheep rumen.) Annales de Biologie Animale, Biochimie, Biophysique 19, 619-624.

Jouany, J. P. \& Senaud, J. (1979c). Description d'une technique permettant d'effectuer des prélèvements répétés de gaz dans le rumen. [A technique for repeated sampling of rumen gases.] Annales de Biologie Animale, Biochimie, Biophysique 19, 1007-1010.

Jouany, J. P. \& Senaud, J. (1982). Influence des ciliés du rumen sur la digestion de diffèrents glucides chez le mouton. I. Utilisation des glucides pariétaux (cellulose et hémicelluloses) et de l'amidon. [Effect of rumen ciliates on the digestion of different carbohydrates in sheep 1. Utilisation of cell-wall carbohydrates (cellulose and hemicellulose) and starch.] Reproduction, Nutrition, Développement 22, 735-752.

Jouany, J. P. \& Senaud, J. (1983). Influence des cilies du rumen sur la digestion de differents glucides chez le mouton. II. Régimes contenant de l'inuline, du saccharose et du lactose. [Effect of rumen ciliates on the digestive utilization of various carbohydrate-rich diets and on the end-products formed in the rumen. II. Utilization of inulin, saccharose and lactose.] Reproduction, Nutrition, Développement 23, 607-623.

Jouany, J. P., Zainab, B., Senaud, J., Groliere, C. A., Grain, J. \& Thivend, P. (1981). Role of rumen ciliate protozoa Polyplastron multivesiculatum, Entodinium sp. and Isotricha prostoma in the digestion of a mixed diet in sheep. Reproduction, Nutrition, Développement 21, 874-884.

Kaneko, T., Ushida, K. \& Kojima, Y. (1989). The effect of starch on cellulolysis by rumen microbial populations with or without protozoa. In The Roles of Protozoa and Fungi in Ruminant Digestion, pp. 313-315 [J. V. Nolan, R. A. Leng and D. I. Demeyer, editors]. Armidale, NSW: Penambul Books.

Kayouli, C., Demeyer, D. I. \& Dendooven, R. (1983-4). Effect of defaunation on straw digestion in sacco and on particle retention in the rumen. Animal Feed Science and Technology 10, 165-172.

Kayouli, C., Van Nevel, C. \& Demeyer, D. (1983). Effet de la défaunation du rumen sur la dégradabilité des proteines du soja mesurée "in sacco". IVth International Symposium "Protein metabolism and nutrition" Clermont-Ferrand (France), Les Colloques de IINRA, No 16, pp. 251-254. [P. Pion, M. Arnal \& D. Bonin, editors]. Versailles, France: INRA Publications.

Kayouli, C., Van Nevel, C. J. \& Demeyer, D. I. (1986). Effect of defaunation and refaunation on the rumen fermentation and $\mathrm{N}$-flow in the duodenum of sheep. Archives of Animal Nutrition (Berlin) 36, 827-837.

Kreuzer, M., Kirchgessner, M. \& Muller, H. L. (1986). Effect of defaunation on the loss of energy in wethers fed 
different quantities of cellulose and normal or steamflaked maize starch. Animal Feed Science and Technology 16, 233-241.

Kurihara, Y., Eadie, J. M., Hobson, P. N. \& Mann, S. O. (1968). Relationship between bacteria and ciliate protozoa in the sheep rumen. Journal of General Microbiology 51, 267-287.

Kurihara, Y., Takechi, T. \& Shibata, F. (1978). Relationship between bacteria and ciliate protozoa in the rumen of sheep fed on a purified diet. Journal of Agricultural Science, Cambridge 90, 373-381.

Leng, R. A. (1982). Dynamics of protozoa in the rumen of sheep. British Journal of Nutrition 48, 399415.

Meyer, J. H. F., Van Der Walt, S. T. \& Schwartz, H. M. (1986). The influence of diet and protozoal numbers on the breakdown and synthesis of protein in the rumen of sheep. Journal of Animal Science 62, 509-520.

Romulo, B. H., Bird, S. H. \& Leng, R. A. (1986). The effects of defaunation on digestibility and rumen fungi counts in sheep fed high-fibre diets. Proceedings of Australian Society of Animal Production 16, 327-330.

Rowe, J. B., Davies, A. \& Broome, A. W. J. (1985). Quantitative effects of defaunation on rumen fermentation and digestion in sheep. British Journal of Nutrition 54, 105-119.

Soetanto, H., Gordon, G. L. R., Hume, I. D. \& Leng, R. A. (1985). The role of protozoa and fungi in fibre digestion in the rumen of sheep. In Efficient Animal Production for Asian Welfare. Proceedings of the third AAAP Animal Science Congress, vol. 2, pp. 805-807. [The Scientific Committee of Congress, cditor] Seoul, Korea: The organizing Committee of the third AAAP Animal Science Committee.

Stern, M. D. \& Hoover, W. H. (1979). Methods for determining and factors affecting rumen microbial protein synthesis: A review. Journal of Animal Science 49, 1590-1970.

Theander, O. \& Aman, P. (1979). Studies of dietary fibres. 1. Analysis and chemical characterization of water soluble and water insoluble dietary fibres. Swedish Journal of Agricultural Research 9, 97-106.

Ushida, K. \& Jouany, J. P. (1985), Effect of protozoa on rumen protein degradation in sheep. Reproduction, Nutrition, Développement 25, 1075-1081.

Ushida, K., Jouany, J. P. \& Demeyer, D. I. (1990). Effects of presence or absence of rumen protozoa on the efficiency of utilization of concentrate and fibrous feeds. In Physiological Aspects and Metabolism in Ruminant. In press [T. Tsuda, Y. Sasaki and R. Kawashima, editors]. San Diego, California: Academic Press.

Ushida, K., Jouany, J., Lassalas, B. \& Thivend, P. (1984). Protozoal contribution to nitrogen digestion in sheep. Canadian Joumal of Amimal Saience 64, Suppl., 2021.

Ushida, K., Jowany, J. P. \& Thivend, P. (1986). Rolc of rumen protozoa in nitrogen digestion in sheep given two isonitrogenous diets. British Journal of Nutrition 56, 407-419.

Ushida, K., Kaneko, T. \& Kojima, Y. (1987). Effect of presence of large entodiniomorphid protozoa on the rumen bacterial flora, fauna composition of small entodinia and in vitro cellulolysis and xylanolysis. Japanese Journal of Zootechnical Science 58, 893-902.

Ushida, K., Takagi, K., Tanaka, H. \& Kojima, Y. (1989). Muralytic activities of fungal and bacterial fractions of defaunated rumen fluid against intact or ncutral detergent-treated roughages. Asian-Australasian Journal of Animal Science 2, 439440.

Van Soest, P. J. \& Wine, R. H. (1967). Use of detergents in the analysis of fibrous feeds. IV. Determination of plant cell-wall constituents. Journal of Association of Official Analytical Chemists 50, 50-55.

Veira, D. M., Ivan, M. \& Jui, P. Y. (1983). Rumen ciliate protozoa: Effects on digestion in the stomach of sheep. Journal of Dairy Science 66, 1015-1022.

Weller, R. A. \& Pilgrim, A. F. (1974). Passage of protozoa and volatile fatty acids from the rumen of the sheep and from a continuous in vitro fermentation system. British Journal of Nutrition 32, 341-351.

Williams, A. G. \& Coleman, G. S. (1985). Hemicellulose-degrading enzymes in rumen ciliate protozoa. Current Microbiology 12, 85-90.

Williams, A. G. \& Orpin, C. G. (1987). Glycoside hydrolase enzymes present in the zoospore and vegetative growth stages of the rumen fungi Neocallimastix patriciarum, Piromonas communis, and an unidentified isolate, grown on a range of carbohydrate. Canadian Joumal of Microbiology 33, 427-434.

Williams, A. G. \& Strachan, N. H. (1984). The distribution of polysaccharide degrading enzymes in the bovine rumen digesta ecosystems. Current Microbiology 10, 215-220.

Williams, A. G., Strachan, N. H. \& Ellis, A. B. (1988). Factors affecting the xylanolytic enzyme activity of microbial populations recovered from the liquid and solid phases of the rumen ecosystem. In Perspectives in Microbial Ecology, Proceedings of IVth International Symposium on Microbial Ecology. pp. 597-602 [F. Megusar and M. Ganter, editors]. Ljubljana, Yugoslavia: Slovene Society for Microbiology.

Williams, A. G., Withers, S. E. \& Coleman, G. S. (1984). Glycoside hydrolases of rumen bacteria and protozoa. Current Microbiology 10, 287-294.

Yoder, R. D., Trenkle, A. \& Burroughs, W. (1966). Influence of rumen protozoa and bacteria upon cellulose digestion in vitro. Journal of Animal Science 25, 609-612. 